Article

\title{
Inheritance of Antibiosis Resistance to the Dectes Stem Borer, Dectes texanus, in Soybean PI165673
}

\author{
Lina M. Aguirre-Rojas ${ }^{1}$, Lawrent L. Buschman ${ }^{2}$, Brian McCornack ${ }^{2}$, William T. Schapaugh ${ }^{3}$, Erin D. Scully ${ }^{4}$, \\ Kun Yan Zhu ${ }^{2}{ }^{D}$, Harold N. Trick ${ }^{5}$ and Charles Michael Smith ${ }^{2, *}$ \\ 1 Department of Botany and Plant Sciences, University of California Riverside, Riverside, CA 92506, USA; \\ hakusen03@gmail.com \\ 2 Department of Entomology, Kansas State University, Manhattan, KS 66506, USA; lbuschma@ksu.edu (L.L.B.); \\ mccornac@ksu.edu (B.M.); kzhu@ksu.edu (K.Y.Z.) \\ 3 Department of Agronomy, Kansas State University, Manhattan, KS 66506, USA; wts@ksu.edu \\ 4 Stored Product Insect and Engineering Research Unit, USDA-ARS-CGAHR, Manhattan, KS 66502, USA; \\ erin.scully@ars.usda.gov \\ 5 Department of Plant Pathology, Kansas State University, Manhattan, KS 66502, USA; hnt@ksu.edu \\ * Correspondence: cmsmith@ksu.edu
}

Citation: Aguirre-Rojas, L.M.;

Buschman, L.L.; McCornack, B.;

Schapaugh, W.T.; Scully, E.D.;

Zhu, K.Y.; Trick, H.N.; Smith, C.M.

Inheritance of Antibiosis Resistance to

the Dectes Stem Borer, Dectes texanus,

in Soybean PI165673. Agronomy 2021,

11, 738. https://doi.org/10.3390/

agronomy11040738

Received: 5 March 2021

Accepted: 9 April 2021

Published: 10 April 2021

Publisher's Note: MDPI stays neutral with regard to jurisdictional claims in published maps and institutional affiliations.

Copyright: (c) 2021 by the authors. Licensee MDPI, Basel, Switzerland. This article is an open access article distributed under the terms and conditions of the Creative Commons Attribution (CC BY) license (https:/ / creativecommons.org/licenses/by/ $4.0 /)$.

\begin{abstract}
Dectes texanus larvae girdles the stems of soybean and cultivated sunflowers causing significant yield losses in North America. The soybean Plant Introduction (PI) 165673 exhibits antibiosis resistance to the larval stage. The objectives of this study were: (1) to determine the inheritance of D. texanus resistance in PI165673; (2) evaluate PI165673 antibiosis resistance before $21 \mathrm{~d}$ post infestation; (3) evaluate girdling damage in PI16563 at the end of the season. K07-1544/PI165673 $F_{2}$ and $F_{2: 3}$ populations were tested for resistance to D. texanus in 2011 and 2012, and PI165673 antibiosis resistance and girdling damage were evaluated in 2014. Segregation for resistance to D. texanus and heritability estimates in the $F_{2}$ and $F_{2: 3}$ populations indicated that resistance was controlled by two genes with dominant and recessive epistasis. Antibiosis evaluations indicated: (1) PI165673 contained lower number of larvae and eggs relative to the number of oviposition punctures at $15 \mathrm{~d}$ post infestation; (2) the proportion of first-instar larvae was higher in PI165673 at $15 \mathrm{~d}$ post infestation; (3) larvae reach the sixth-instar stage in PI165673. None of the PI165673 plants were girdled at the end of the season. Identification of additional sources of $D$. texanus resistance is required to impair larval development in the stem.
\end{abstract}

Keywords: Dectes texanus; soybean; host-plant resistance; antibiosis; inheritance of resistance

\section{Introduction}

Soybean, Glycine max (L.) Merrill, is an important agricultural crop supplying an increasing demand for animal feed and alternative oil/fuel sources due to its high protein and seed oil content [1,2]. The demand for biodiesel, feed with high protein content and meat and dairy product substitutes has accelerated the growth of soybean production worldwide and the development of high yielding soybean cultivars [3]. Soybean is a widely cultivated crop around the world, and most soybeans were produced in Brazil (37\%), the United States (28\%) and Argentina (16\%) in 2019 [4]. Soybean yield has increased in the United States from $1690 \mathrm{~kg} / \mathrm{ha}$ in 1961 to $3189 \mathrm{~kg} / \mathrm{ha}$ in 2019 [5,6], and this increase in yield is the result of multiple breeding programs that are designed to improve yields, seed composition, pest resistance and tolerance to abiotic stresses [7].

Arthropod pests are a major limiting factor of soybean production worldwide, and approximately $21.4 \%$ of the world soybean yield losses were due to pests in 2017 , with $5.7 \%$ attributed to arthropods and nematodes [8]. The Dectes stem borer, Dectes texanus LeConte (Coleoptera: Cerambycidae), has been a major pest of soybeans and cultivated sunflowers (Helianthus annuus L.) in the Midwestern United States since 1968 and 1970, respectively [9]. 
Dectes texanus larvae damage soybeans and sunflowers when they enter the main stem, tunnel to the base of the plant and girdle the stem $[10,11]$. Soybean yield losses occur when the plant breaks at the girdle point prior to harvest [10-12]. Adults feed on the epidermis of petioles and stems. Feeding damage for this life stage is not extensive nor is directly related to yield loss $[10,12]$. The number of U.S. States reporting $D$. texanus infestations in soybean increased from one in 1968 to 18 in 2019, indicating that their pest distribution has expanded [11,13-17]. Changes in the natural landscape (expansion of soybean production and reduction in wild hosts) and agricultural practices (from tillage to non-tillage) may have promoted the use of soybean as a host by $D$. texanus $[10,13]$. Harvesting as soon as possible and spraying insecticides that target the adult stage represent the current practices to avoid significant borer-related yield losses $[13,18]$.

Host-plant resistance to arthropods is a fundamental component of crop improvement and integrated pest management $[19,20]$. Soybean varieties resistant to $D$. texanus are sought because the larval stage causes $5-15 \%$ yield reductions and $10 \%$ physiological yield loss $[13,21]$, commercial insecticides fail to kill the larvae inside stems and require multiple applications to effectively manage adults [18], and the cost of D. texanus management is included in the seed price $[20,22]$. Identification of soybean genotypes and cultivars resistant to $D$. texanus was inconsistent based on the percentage of larval infestation, tunneling, girdling and lodging until an antibiosis ratio (number of oviposition punctures $(\mathrm{OvP}) /$ number of larvae) was used to assess resistance [23-25]. This antibiosis ratio corrected for cultivar differences in number of oviposition punctures, and it was evaluated early in the season when beetles were active in the field [26]. Based on this ratio, the soybean Plant Introduction (PI) 165673 showed antibiosis resistance to D. texanus that reduced the number of larvae compared to the susceptible control 93M50 and 93M50protected with fipronil systemic insecticide at 21 days post infestation [26]. Antibiosis resistance is a category of host-plant resistance to arthropods and refers to the adverse effects of a resistant plant on the survival, development, or fecundity of an arthropod and its population [20].

In order to develop soybean genotypes resistant to $D$. texanus, information about the inheritance of the resistance in PI165673 and the number of genes controlling the resistance trait(s) are needed in order to establish appropriate breeding strategies. Additionally, it is of interest to determine if the resistant genotype impacted larval development; assess antibiosis resistance before $21 \mathrm{~d}$ post infestation to reduce the time needed for screening resistance; evaluate whether larvae survive and girdle the PI165673 at the end of the growing season. Therefore, the objectives of this research were to determine the inheritance of $D$. texanus resistance in PI165673, evaluate antibiosis resistance before $21 \mathrm{~d}$ post infestation, and evaluate stem girdling and tunneling by $D$. texanus at the end of the season. Information provided from this research will benefit soybean breeding programs by identifying $D$. texanus resistant progeny lines that can be improved for agronomic qualities. These lines can also be used to locate resistance gene(s) within the genome, and to identify molecular markers linked to the resistance. Ultimately, this research can contribute to the development of new genotypes that can be used to increase yields in areas affected by $D$. texanus.

\section{Materials and Methods}

\subsection{Inheritance Experiments}

\subsection{1. $F_{2}$ and $F_{2: 3}$ K07-1544/PI165673 Population Development}

Two populations were created using two soybean genotypes, KS5004N and K07-1544, that were crossed with the D. texanus-resistant genotype PI165673 in a winter nursery in Costa Rica. These crosses were made with the assumption that KS5004N and K07-1544 had contrasting susceptible phenotypes relative to PI165673. Pollen from PI165673 was transferred to the stigma of emasculated flowers of both susceptible genotypes, and $F_{1}$ seeds were harvested and selfed to produce the $\mathrm{F}_{2}$ generation for each cross. Hypocotyl color of $F_{2}$ plants fit a 3 purple: 1 green segregation ratio which confirmed that they came from a cross pollinated female plant flower. Plants from this filial generation were evaluated 
for resistance to $D$. texanus in summer 2011. Remnant $F_{2}$ seeds were further advanced to the $\mathrm{F}_{3}$ generation, but only $\mathrm{F}_{2: 3}$ families from the cross K07-1544/PI165673 were screened for resistance in summer 2012 because of limited numbers of cages and logistic constraints that did not allow for the evaluation of two different $\mathrm{F}_{2: 3}$ populations at the same time.

\subsubsection{Field Experiment with $\mathrm{F}_{2}$ Populations}

$F_{1}$ and $F_{2}$ plants from both populations, KS5004N/PI165673 and K07-1544/PI165673, were evaluated for $D$. texanus resistance in a field choice test in summer 2011 . KS5004N, a maturity group V cultivar, was an $\mathrm{F}_{4}$ plant selection from the cross KS5292 X SC91-2007. K07-1544, a maturity group III experimental line, was an $\mathrm{F}_{4}$ plant selection from the cross IA3023 X LD00-3309. Two $3 \times 3$ m plots were planted per population at the Kansas State University North Agronomy Farm in Manhattan, KS. Five $\mathrm{F}_{1}$ and $155 \mathrm{~F}_{2}$ seeds per cross, and 10 PI165673 and 10 susceptible parental control seeds were hand planted $\sim 2.5 \mathrm{~cm}$ deep in a completely randomized design per plot. Each plot contained four $2.3 \mathrm{~m}$ long rows, and seeds were spaced $5 \mathrm{~cm}$ apart within a row. A total of 104 and $117 \mathrm{~F}_{2}$ healthy seedlings emerged in the KS5004N/PI165673 and K07-1544/PI165673 plots, respectively, which represented an approximate $70 \%$ rate of seedling survival. Survival was likely reduced due to poor germination, drought, or seedling damage by other arthropods. Nevertheless, this rate of stand establishment is within the range of normal soybean germination in small field plot experiments. K07-1544 seeds were sown in rows surrounding the plots. Plots were irrigated using sprinkler cans due to lack of rainfall and were caged $35 \mathrm{~d}$ after planting with $3 \times 3$ m canopy tents (Columbia ${ }^{\circledR}$, Columbia Sportswear, Portland, OR, USA). Canopy roofs and cage side mesh panels were sealed with duct-tape, and the bottom of the mesh was anchored to the ground and buried with soil to prevent beetle escape. Dectes texanus adults were collected from giant ragweed patches and soybean fields in Scandia, Abilene and the Kansas State University Ashland Bottoms Research Station, near Manhattan, KS, and released in each cage at a rate of two unsexed beetles per plant, $35 \mathrm{~d}$ after planting. Dectes texanus adults have sexual monomorphism and are distributed in a 1 female: 1 male ratio in the field [12]. The top petiole on each plant was marked on the plant stem when cages were infested. Plants were cut at the soil level $21 \mathrm{~d}$ after infestation and stored in a $4{ }^{\circ} \mathrm{C}$ cold room. Oviposition punctures and larvae on each plant were counted on the five petioles below the infestation mark following recommendations of Niide (2009) [27]. With this information, the OL antibiosis ratio (number of OvP/number of larvae) was calculated for each plant to evaluate $D$. texanus resistance. Plants with an OL antibiosis ratio of one were considered susceptible, and plants with an antibiosis ratio of zero were considered missing data because they could have been plants that escaped infestation.

\subsubsection{Field Experiment with $\mathrm{K} 07-1544 / \mathrm{PI} 165673 \mathrm{~F}_{2: 3}$ Families}

One hundred eight K07-1544/PI165673 $\mathrm{F}_{2: 3}$ families and the two parental genotypes were evaluated for $D$. texanus resistance in a randomized complete block design with 14 replicates in a field choice test in summer 2012. One seed per $F_{2: 3}$ family and six seeds per parent were hand planted in each block (replicate) in a $3 \times 3 \mathrm{~m}$ plot with four $2.3 \mathrm{~m}$ long rows and $7.6 \mathrm{~cm}$ spacing between seeds. Plots were located at the Kansas State University North Agronomy Farm in Manhattan, KS, were caged $35 \mathrm{~d}$ after planting as mentioned above, and were irrigated with sprinklers due to lack of rainfall. K07-1544 seeds were planted in rows surrounding and between plots. Dectes texanus adults were collected from the same locations mentioned above and were released in each cage at a rate of two unsexed beetles per plant, $49 \mathrm{~d}$ after planting. Infestation was delayed because strong winds damaged nine cages, and they needed repairing or replacement. Plants were cut at the soil level $21 \mathrm{~d}$ after infestation and stored in $-20^{\circ} \mathrm{C}$ and $-80{ }^{\circ} \mathrm{C}$ freezers. The numbers of oviposition punctures, larvae and the OL antibiosis ratio were calculated for each plant as indicated above. Larval head capsule width and body length were measured from undamaged larvae collected from K07-1544 and PI165673 plants that were preserved in Pampel's solution, BioQuip Products Inc. (Rancho Dominguez, CA, USA). Head capsule 
and body length measurements were made using a Leica ${ }^{\circledR}$ MZ APO and a Nikon ${ }^{\circledR}$ SMZ645 stereomicroscope, respectively. Head capsules were measured across their widest point using the software Leica ${ }^{\circledR}$ Application Suite V.3.4.0 (Buffalo Grove, IL, USA) at 60X. Larval instar was determined based on the head capsule width range described for each $D$. texanus instar by Hatchett et al. (1975) [12].

\subsubsection{Statistical Analyses of Field Experiments with $F_{2}$ and $F_{2: 3}$ Populations}

Analyses of variances were performed for the numbers of oviposition punctures, numbers of larvae, and OL antibiosis ratios using a generalized mixed model where the $\mathrm{F}_{2: 3}$ families and parental genotypes were considered fixed effects, and blocks (cages) were random effects. $F_{1}$ and $F_{2}$ populations were excluded from the analysis as each $F_{1}$ and $F_{2}$ seed was considered a unique recombination event. Independent analyses of variances were performed with the 2011 and 2012 data. Statistical analyses were conducted using a PROC GLIMMIX procedure (SAS Institute, Cary, NC, USA) with a gamma distribution and a log link function since data were positively skewed and did not follow homogeneity of variances. Estimation of degrees of freedom was performed using the Satterthwaite method [28,29]. When the F-test was significant at $p<0.05$, pairwise comparisons were conducted with a Fisher's protected least significant difference test (LSD) at $\alpha=0.05$ significance level. LSD tests were performed because the number of possible comparison combinations was large [30].

The broad sense heritability was estimated for the OL antibiosis ratio of the $\mathrm{F}_{2: 3}$ families K07-1544/PI165673. The broad sense heritability was estimated as follows: $\mathrm{H}^{2}=\left(\left(\sigma^{2} \mathrm{~F}-\sigma^{2} \mathrm{e}\right) / \sigma^{2} \mathrm{~F}\right) \times 100$, where $\sigma^{2} \mathrm{~F}$ is the phenotypic variance of the $\mathrm{F}_{2: 3}$ plant populations, and $\sigma^{2} \mathrm{e}$ is the variance of environmental origin $[19,31]$. The parental genotypes were used to calculate the $\sigma^{2}$ e variance among the $\mathrm{F}_{2: 3}$ populations, respectively. Their phenotypic variance was partitioned into their respective variance components $\left(\sigma^{2}\right.$ genotype, $\sigma^{2}$ cage, $\sigma^{2}$ cage ${ }^{*}$ genotype, and $\sigma^{2}$ error) since there were replicates for each parental genotypes per cage in the experiment [28]. The $\sigma^{2}$ cage, $\sigma^{2}$ cage $\times$ genotype and $\sigma^{2}$ error were used to calculate the environmental variance. The variance components were calculated using a PROC MIXED procedure (SAS Institute, Cary, NC, USA) where the parental genotype and cage were considered as fixed and random effects, respectively.

Analyses of variances using PROC GLIMMIX with a normal distribution were calculated for mean larval head capsule width and mean body length from larvae collected in K07-1544 and PI165673 plants in 2012. A Pearson's chi-square test was calculated to compare the numbers of larvae per instar from K07-1544 and PI165673 plants using a PROC FREQ procedure (SAS Institute, Cary, NC, USA).

\subsection{Field Experiment with K07-1544 and PI165673 Genotypes}

K07-1544 and PI165673 were further evaluated for D. texanus resistance at the Kansas State University Ashland Bottoms Research Station, near Manhattan, KS, in summer 2014. The experiment was conducted in a $12.2 \times 12.2 \mathrm{~m}$ plot that contained 380 planting spots, spaced $61 \mathrm{~cm}$ apart in every cardinal direction. Three seeds per genotype were hand planted, about $2.5 \mathrm{~cm}$ deep, in a planting spot that was assigned at random to each genotype. Three seeds were planted to secure at least one plant per spot because PI165673 had $<30 \%$ seed germination in a moist filter paper assay. Only one seedling per planting spot was kept after emergence, and only 110 spots had a PI165673 plant. Rows surrounding the plot were planted with K07-1544 seed.

Each plant was caged with a galvanized tomato frame $(0.6 \mathrm{~m}$ diam $\times 1.4 \mathrm{~m}$ height $)$ covered with a mosquito mesh $(1 \mathrm{~m}$ diam $\times 2 \mathrm{~m}$ height $) 21 \mathrm{~d}$ after planting. Cages were held to the ground using a $2 \mathrm{~m}$ rebar and $23 \mathrm{~cm}$ tent stakes. The bottom and top of the mesh were buried with soil and tied with a knot, respectively, to prevent the beetles from escaping and other insects from entering. Thirty days after planting, each cage was infested with four unsexed $D$. texanus beetles that were collected from soybean fields in the research station. Plants were sampled at seven dates $(7,9,11,13,15,21$ and $120 \mathrm{~d})$ 
post infestation, and the number of plants sampled per date are listed in Supplementary Table S1. Sampling at $120 \mathrm{~d}$ after infestation (after the first freeze) was divided into ten consecutive sampling days (blocks) due to the logistical constraints of sampling all plants in the same day. Five plants per genotype were evaluated at each sampling day after the first freeze on 29 October 2014 [32]. About 30\% of the plants per each genotype lacked $D$. texanus oviposition punctures; most likely because beetles became stuck at the top of the mesh before oviposition (Supplementary Table S1). These plants were not considered in the data analyses.

The numbers of oviposition punctures, eggs, larvae, and stem entrance holes; plant height; stem and tunnel length; girdling damage were counted, measured and evaluated for each plant, respectively. An OEL antibiosis ratio (number of oviposition punctures/[number of eggs + number of larvae]) and an OL antibiosis ratio were calculated for each sampling date, except at $120 \mathrm{~d}$ post infestation, when only the OL antibiosis ratio was calculated since no eggs were found in plants sampling. Larvae were collected from each plant, and head capsules were measured across their widest point using a Leica ${ }^{\circledR} \mathrm{MZ}$ APO stereomicroscope at 40X. Larval instar was determined based on the head capsule width range described for each $D$. texanus instar by Hatchett et al. 1975 [12]. The Dectes texanus head capsule width ranges were described until the sixth-instar stage by these authors [12]. Thus, larvae with a head capsule width exceeding this range were considered sixth instar.

\subsection{Statistical Analyses of Experiment with K07-1544 and PI165673 Genotypes}

The numbers of oviposition punctures, eggs, larvae, and stem entrance holes; OEL and OL antibiosis ratios; percentage of stem tunneling, and larval head capsule widths were assessed for normality and homogeneity of variances at each sampling date using Kolmogorov-Smirnov [33], Levene [34] and Brown-Forsythe [35] tests (Supplementary Table S2). When data did not follow normality and homogeneity of variances, a Poisson or negative binomial distribution was used to analyze the data, after the fitness of both distributions had been assessed based on a Pearson's chi-square/DF statistic for conditional distributions $[36,37]$. The type of distribution used for each response variable is listed in Supplementary Table S3. The type III test of fixed effects was used to compare data of both genotypes with the PROC GLIMMIX procedure [38] and the Kenward-Rogers approximation [39] for estimation of degrees of freedom. Each sampling date was analyzed independently, where genotype was considered the fixed effect in the model. Sampling day after $120 \mathrm{~d}$ post infestation was considered a blocking factor and a random effect in the model [28]. When the F-test was significant $(p<0.05)$, means were given a different uppercase letter.

The percentage of larvae per instar, girdled plants and tunnels reaching the plant base were analyzed using a Pearson's chi-square test using the PROC FREQ procedure (SAS Institute, Cary, NC, USA) [40]. When the percentage of larvae per instar was significant $(p<0.05)$, Fisher's exact tests were conducted per instar between genotypes. A chi-square distribution was used because data convergence failed using a binomial distribution. SAS v. 9.2 (SAS Institute, Cary, NC, USA) was used to perform all statistical analyses.

\section{Results}

\subsection{Field Experiments with $F_{2}$ and $F_{2: 3}$ Populations}

The numbers of oviposition punctures and larvae, and the OL antibiosis ratio were not significantly different between the susceptible parents (KS5004N, K07-1544) and the resistant genotype PI165673 in 2011 (Table 1). The frequency distributions of the data for OL antibiosis ratios, numbers of oviposition punctures and numbers of larvae were continuous, skewed to the right, and extended beyond most of the phenotypic ranges of the parents for both $\mathrm{F}_{2}$ populations (Figures 1-3). 
Table 1. Mean \pm SEM OL antibiosis ratios, and number of oviposition punctures and number of larvae per plant in $F_{2}$ soybean populations KS5004N/PI165673 and K07-1544/PI165673 at 21 d post infestation with Dectes texanus in 2011.

\begin{tabular}{|c|c|c|c|c|c|}
\hline \multirow[b]{2}{*}{$F_{2}$ Population } & \multirow[b]{2}{*}{ Genoytpe } & \multirow[b]{2}{*}{$n$} & \multicolumn{3}{|c|}{ Mean \pm SEM } \\
\hline & & & OL Antibiosis Ratio & \# Oviposition Punctures & \# Larvae \\
\hline \multirow[t]{2}{*}{ KS5004N/PI165673 ${ }^{a}$} & KS5004N & 18 & $1.9 \pm 0.6^{a}$ & $7.1 \pm 2.4^{\mathrm{a}}$ & $3.3 \pm 0.4^{\mathrm{a}}$ \\
\hline & PI165673 & 6 & $2.1 \pm 0.7^{\mathrm{a}}$ & $6.7 \pm 2.7^{\mathrm{a}}$ & $3.7 \pm 0.7^{\mathrm{a}}$ \\
\hline \multirow[t]{2}{*}{ K07-1544/PI165673 b } & K07-1544 & 8 & $1.2 \pm 0.3^{a}$ & $3.4 \pm 0.9^{a}$ & $2.5 \pm 0.7^{\mathrm{a}}$ \\
\hline & PI165673 & 6 & $1.2 \pm 0.1^{\mathrm{a}}$ & $3.7 \pm 0.7^{\mathrm{a}}$ & $3.0 \pm 0.6^{\mathrm{a}}$ \\
\hline
\end{tabular}

OL antibiosis ratio $=$ (number of oviposition punctures/number of larvae), SEM: Standard Error of Mean; $n$ : number of plants. Means followed by a different lower-case letter within a column for each cross are statistically different based on a Fisher's protected least significant difference test (LSD) $(p<0.05)$ means separation test. Means within a column with same uppercase letter are not significantly different based on an F-test $(p>0.05)$ : ${ }^{a}$ OL antibiosis ratio $\left(\mathrm{F}_{1,21.15}=0.12, p>0.05\right)$, \# oviposition punctures $\left(\mathrm{F}_{1,21.39}=0.03, p>0.05\right)$, \# larvae $\left(\mathrm{F}_{1,22}=0.27, p>0.05\right) .{ }^{\mathrm{b}}$ OL antibiosis ratio $\left(\mathrm{F}_{1,2.2}=0.02, p>0.05\right)$, \# oviposition punctures $\left(\mathrm{F}_{1,12}=0.06, p>0.05\right) \#$ larvae $\left(\mathrm{F}_{1,12}=0.29\right.$, $p>0.05)$.

a

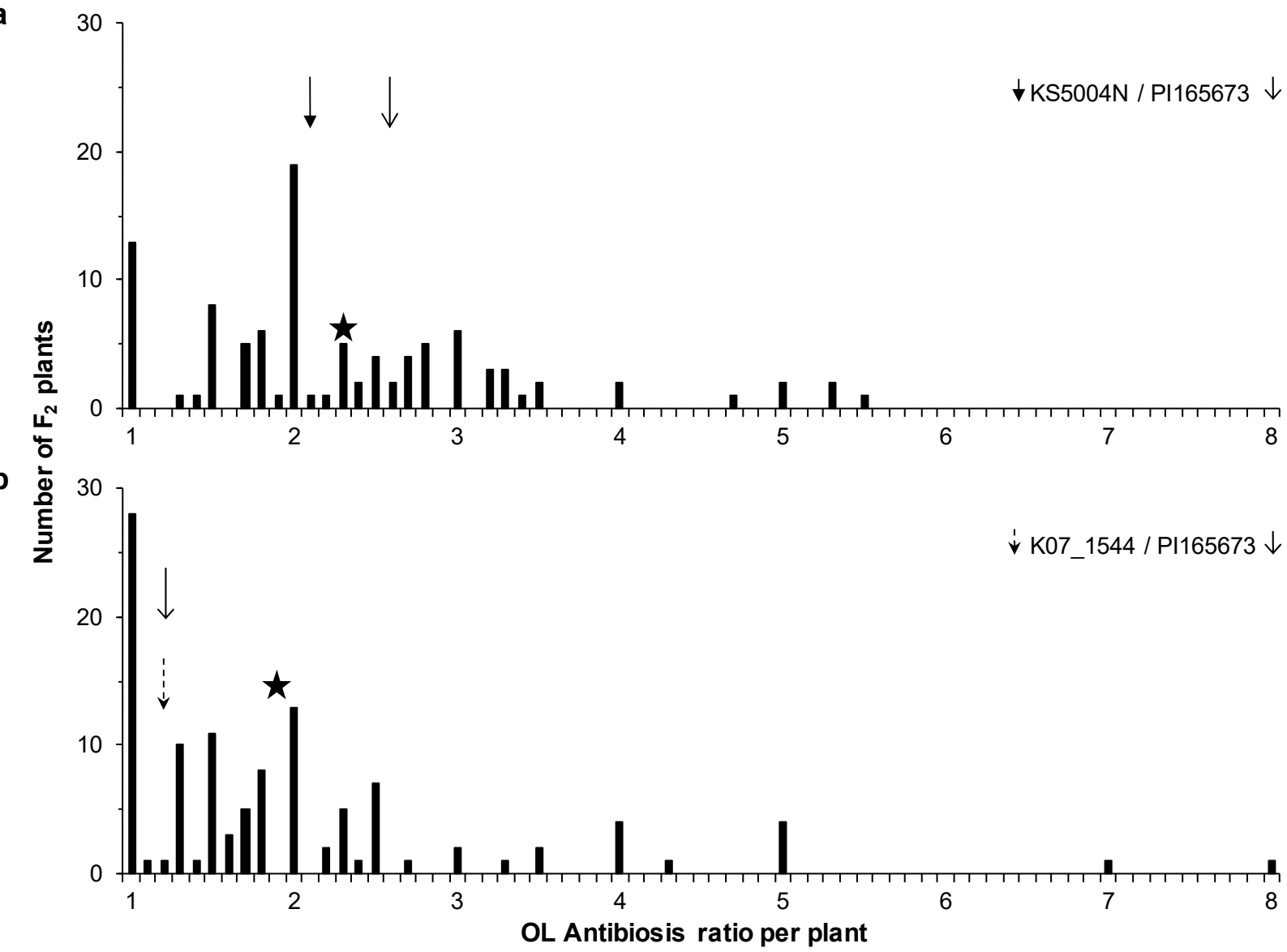

Figure 1. Frequency distributions of OL antibiosis ratios per plant in $\mathrm{F}_{2}$ soybean populations (a) KS5004N/PI165673 and (b) K07-1544/PI165673 at $21 \mathrm{~d}$ post infestation with Dectes texanus in 2011. Arrows and stars indicate parent and $\mathrm{F}_{2}$ means, respectively. OL antibiosis ratio = (number of oviposition punctures/number of larvae). 


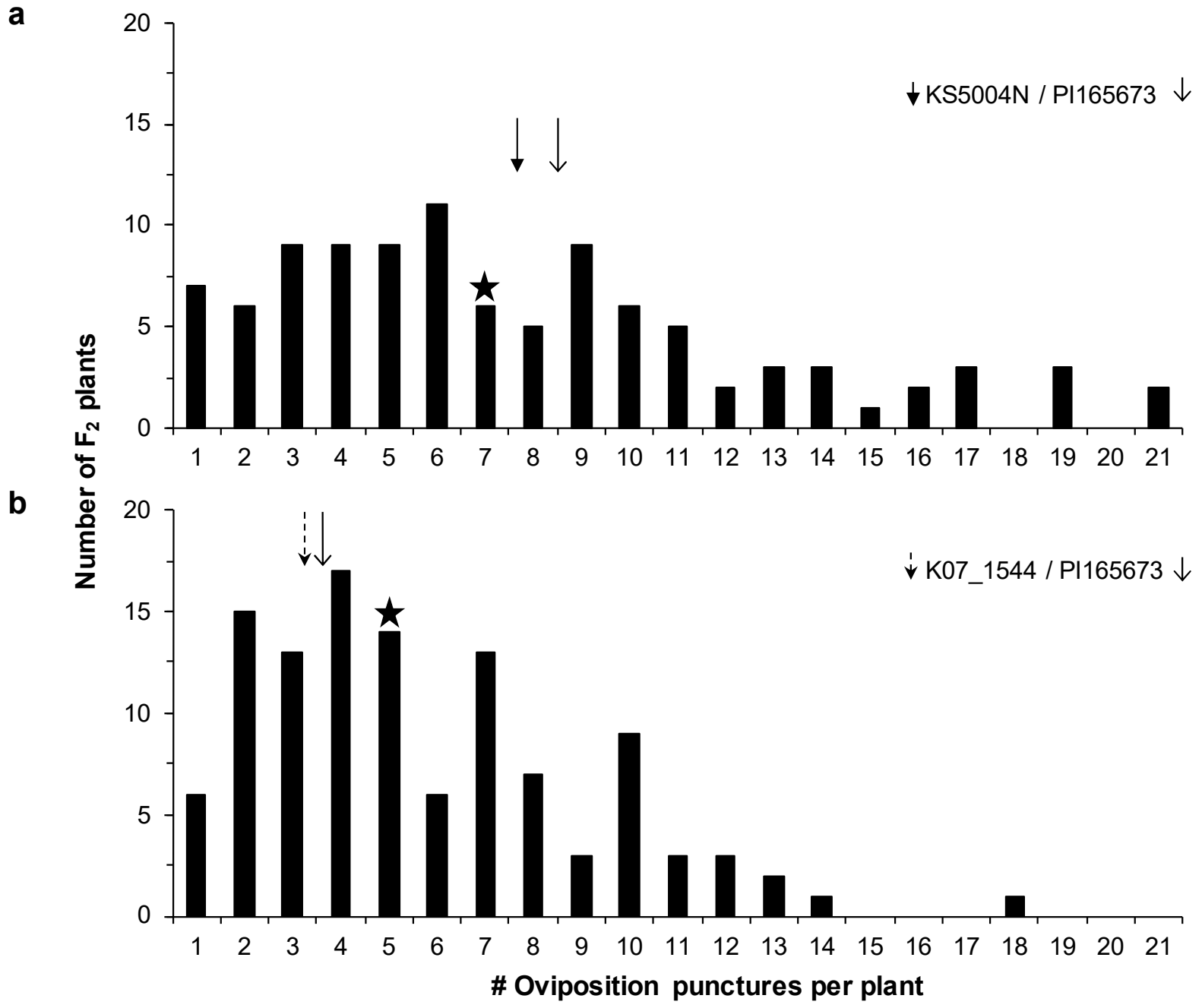

Figure 2. Frequency distributions of number of oviposition punctures per plant in $\mathrm{F}_{2}$ soybean populations (a) KS5004N/PI165673 and (b) K07-1544/PI165673 at $21 \mathrm{~d}$ post infestation with Dectes texanus in 2011. Arrows and stars indicate parent and $\mathrm{F}_{2}$ means, respectively.

Table 2. Mean \pm SEM OL antibiosis ratios, numbers of oviposition punctures, and numbers of larvae per plant in soybean genotypes K07-1544 and PI165673 at 21 d post infestation with Dectes texanus in 2012.

\begin{tabular}{ccccccccc}
\hline & & \multicolumn{3}{c}{ Mean \pm SEM } & & Mean \pm SEM & Mean \pm SEM \\
\cline { 3 - 9 } Genotype & $n$ & $\begin{array}{c}\text { OL Antibiosis } \\
\text { Ratio }\end{array}$ & $\begin{array}{c}\text { \# Oviposition } \\
\text { Punctures }\end{array}$ & \# Larvae & n & $\begin{array}{c}\text { Larval Head Capsule } \\
\text { Width (mm) }\end{array}$ & $\begin{array}{c}\text { Larval Body } \\
\text { Length (mm) }\end{array}$ \\
\hline K07-1544 & 68 & $1.7 \pm 0.1^{\mathrm{a}}$ & $10.3 \pm 1.1^{\mathrm{a}}$ & $6.1 \pm 0.6^{\mathrm{a}}$ & 62 & $0.8 \pm 0.03^{\mathrm{a}}$ & 60 & $7.0 \pm 0.5^{\mathrm{a}}$ \\
PI165673 & 36 & $2.1 \pm 0.2^{\mathrm{b}}$ & $10.8 \pm 1.4^{\mathrm{a}}$ & $5.4 \pm 0.6^{\mathrm{a}}$ & 34 & $0.8 \pm 0.03^{\mathrm{a}}$ & 32 & $7.7 \pm 0.6^{\mathrm{a}}$ \\
\hline
\end{tabular}

OL antibiosis ratio $=$ (number of oviposition punctures/number of larvae), SEM: Standard Error of Mean; $n$ : number of plants. Means followed by a different lower-case letter within a column are statistically different based on a Fisher's protected LSD $(p<0.05)$ means separation test. Means within a column with same uppercase letter are not significantly different based on an F-test $(p>0.05)$. \# oviposition punctures $\left(\mathrm{F}_{1,103}=0.08, p>0.05\right)$, \# larvae: $\left.\mathrm{F}_{1,103}=1.11, p>0.05\right)$, larval head capsule width $\left(\mathrm{F}_{1,85.1}=0.32, p>0.05\right)$, larval body length $\left(\mathrm{F}_{1,12.4}=1.34, p>0.05\right)$. 
a

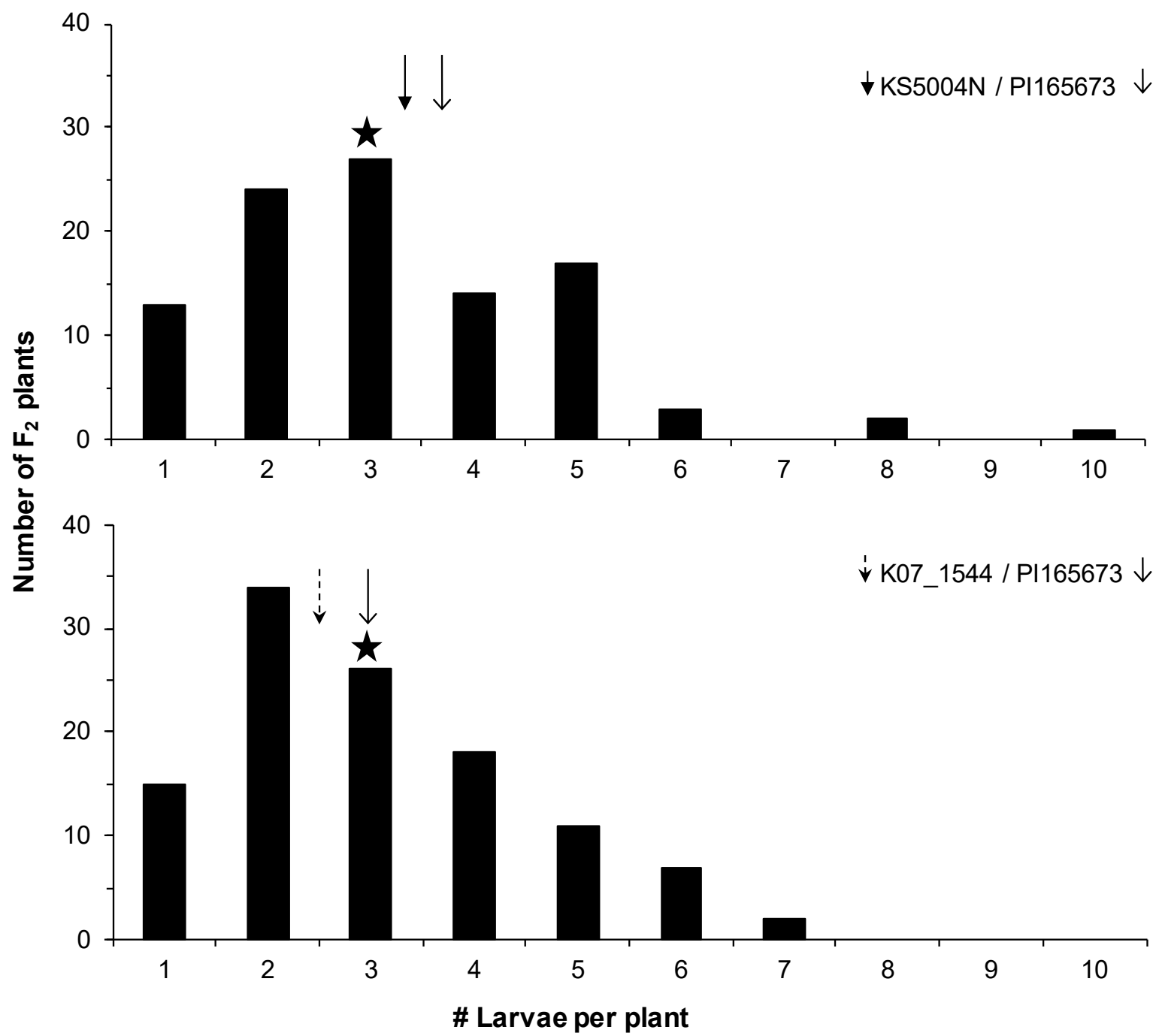

Figure 3. Frequency distributions of number of larvae per plant in $F_{2}$ soybean populations from (a) KS5004N/PI165673 and (b) K07-1544/PI165673 at $21 \mathrm{~d}$ post infestation with Dectes texanus in 2011. Arrows and stars indicate parent and $\mathrm{F}_{2}$ means, respectively. The OL antibiosis ratio was significantly greater in PI165673 plants than K07-1544 plants in $2012\left(\mathrm{~F}_{1,103}=4.37\right.$, $p<0.05$; Table 2). The numbers of oviposition punctures, numbers of larvae, larval head capsule widths, and larval body lengths were not significantly different between these two parental genotypes (Table 2). Additionally, there was no evidence of differences in the percentage of $D$. texanus larvae per instar between these parents (Pearson's $\chi^{2}=1.86, \mathrm{df}=4, p>0.05$ ). Approximately $50 \%$ of larvae from plants of both genotypes were in the third instar at the time of sampling (Figure 4). 


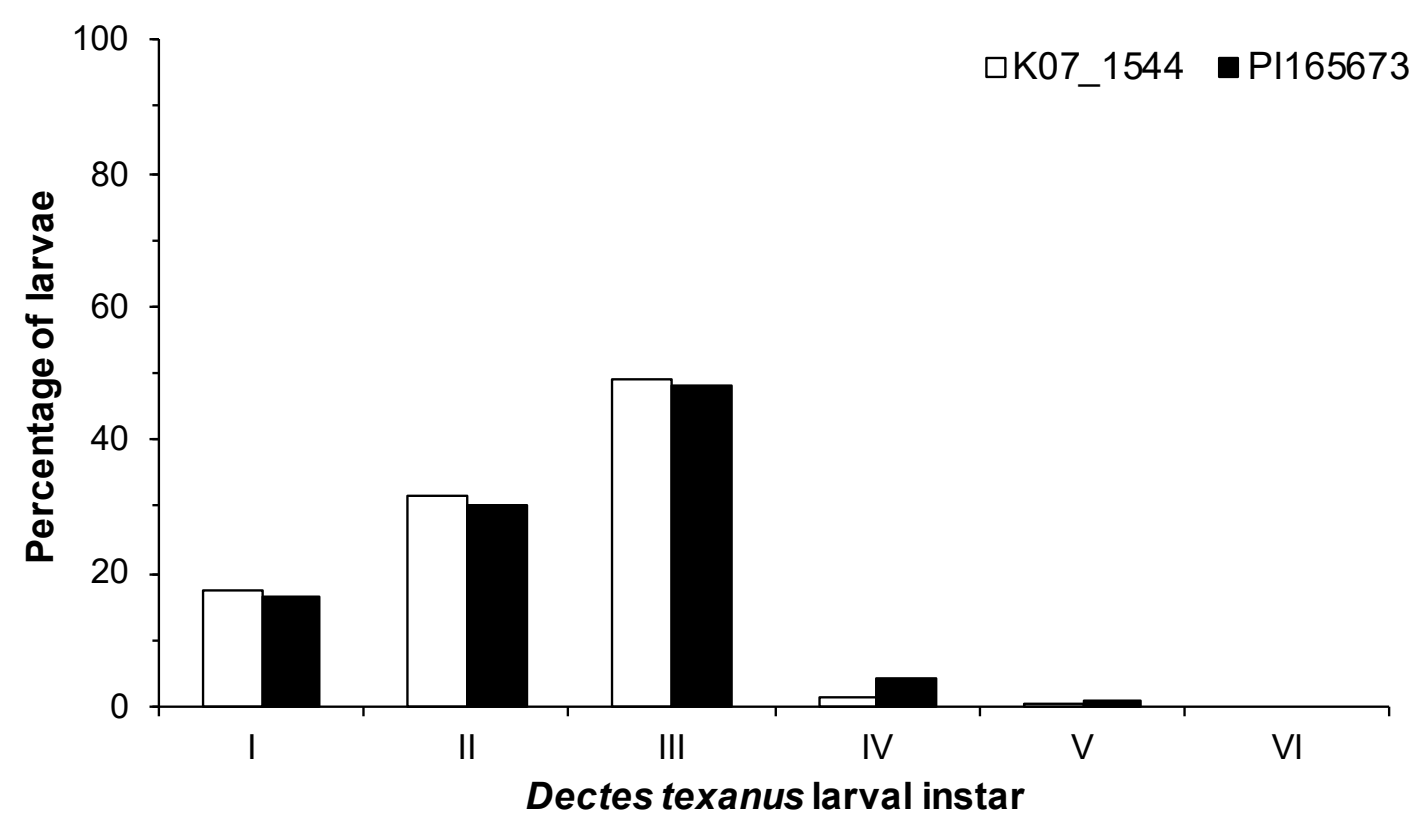

Figure 4. Percentage of Dectes texanus larvae per instar collected from plants of soybean genotypes K07-1544 and PI165673 at $21 \mathrm{~d}$ post infestation in 2012.

The frequency distribution of the $\mathrm{F}_{2: 3}$ families was continuous and bell-shaped for all the phenotypic traits evaluated (Figures 5-7). Chi-square goodness of fit tests with the $\mathrm{OL}$ antibiosis ratios of $\mathrm{F}_{2: 3}$ families indicated that resistance is controlled by two genes with dominant and recessive epistasis (Table 3). Other gene models based on complex hierarchical relationships were not tested, due to limitations in assigning phenotypic ratios based on parental phenotypes. Therefore, it is possible that the number of genes contributing to the inheritance of OL antibiosis could be more complex than a two gene model. The broad sense heritability among the families was $68.5 \%$ for the OL antibiosis ratio (Table 4). The OL antibiosis ratios and numbers of oviposition punctures were significantly different between the $\mathrm{F}_{2: 3}$ families and parental genotypes $\left(\mathrm{F}_{109,967.4}=1.31\right.$, $p<0.05 ; \mathrm{F}_{109,969.5}=1.30, p<0.05$, respectively). Thirteen $\mathrm{F}_{2: 3}$ families had a higher OL antibiosis ratio than the susceptible parental genotype, and two of these 13 families had higher ratios than the resistant PI165673 genotype (Supplementary Table S4). Eight families had a lower numbers of oviposition punctures than either parental genotype, and one family had a lower number of oviposition punctures than the resistant parent (Supplementary Table S4). Family 146 was the only family with a higher OL antibiosis ratio than K07-1544 and with a lower number of oviposition punctures than PI165673. There was no evidence of differences between families and parental genotypes for the numbers of larvae $\left(\mathrm{F}_{109,972.5}=1.16, p>0.05\right.$; Supplementary Table $\left.\mathrm{S} 4\right)$. 


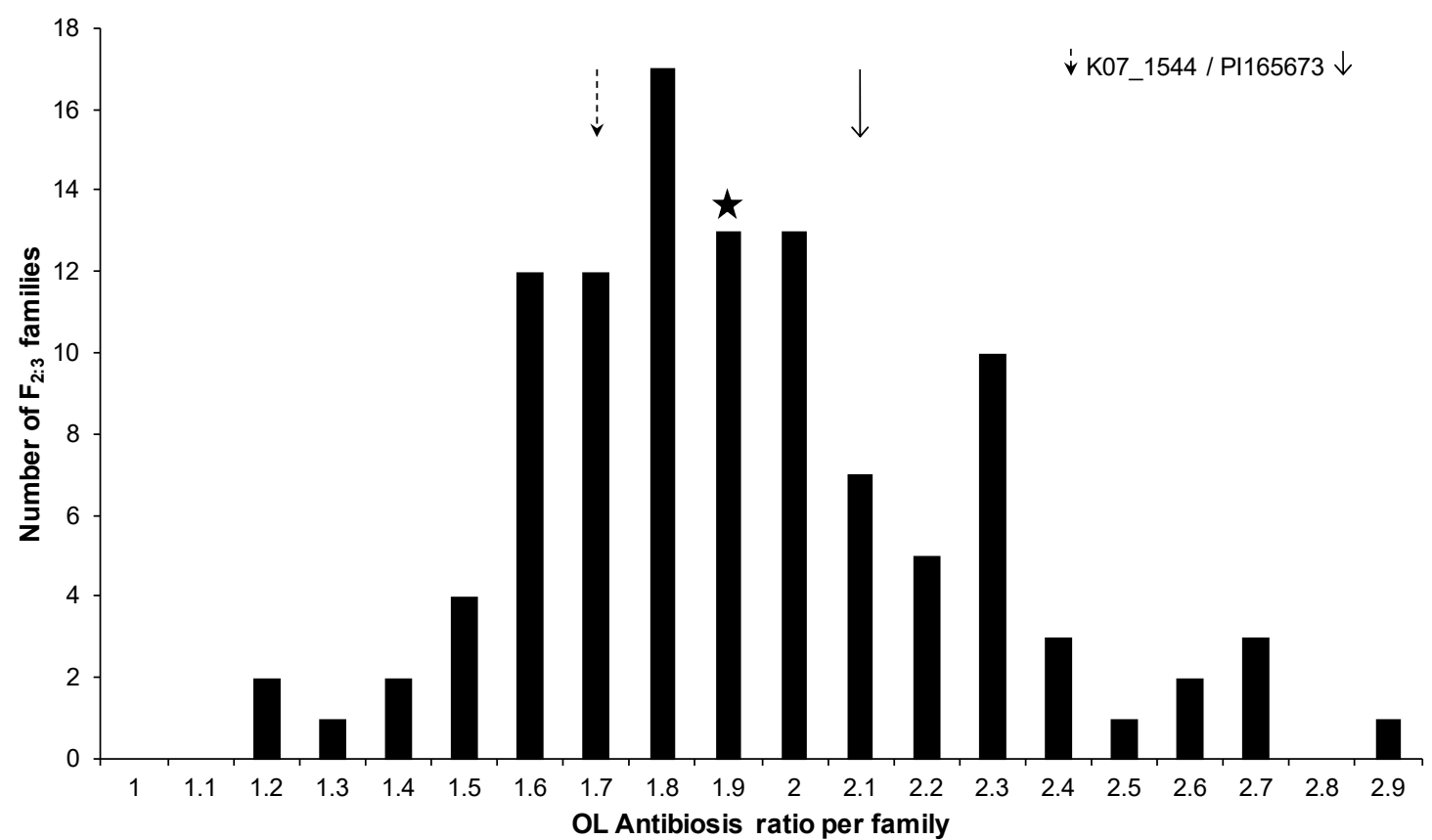

Figure 5. Frequency distribution of the $\mathrm{OL}$ antibiosis ratio in plants from $108 \mathrm{~F}_{2: 3}$ families from the cross K07-1544/PI165673 at 21 post infestation with Dectes texanus in 2012. OL antibiosis ratio (number of oviposition punctures/number of larvae). Arrows and star indicate parent and $\mathrm{F}_{2: 3}$ population mean, respectively.

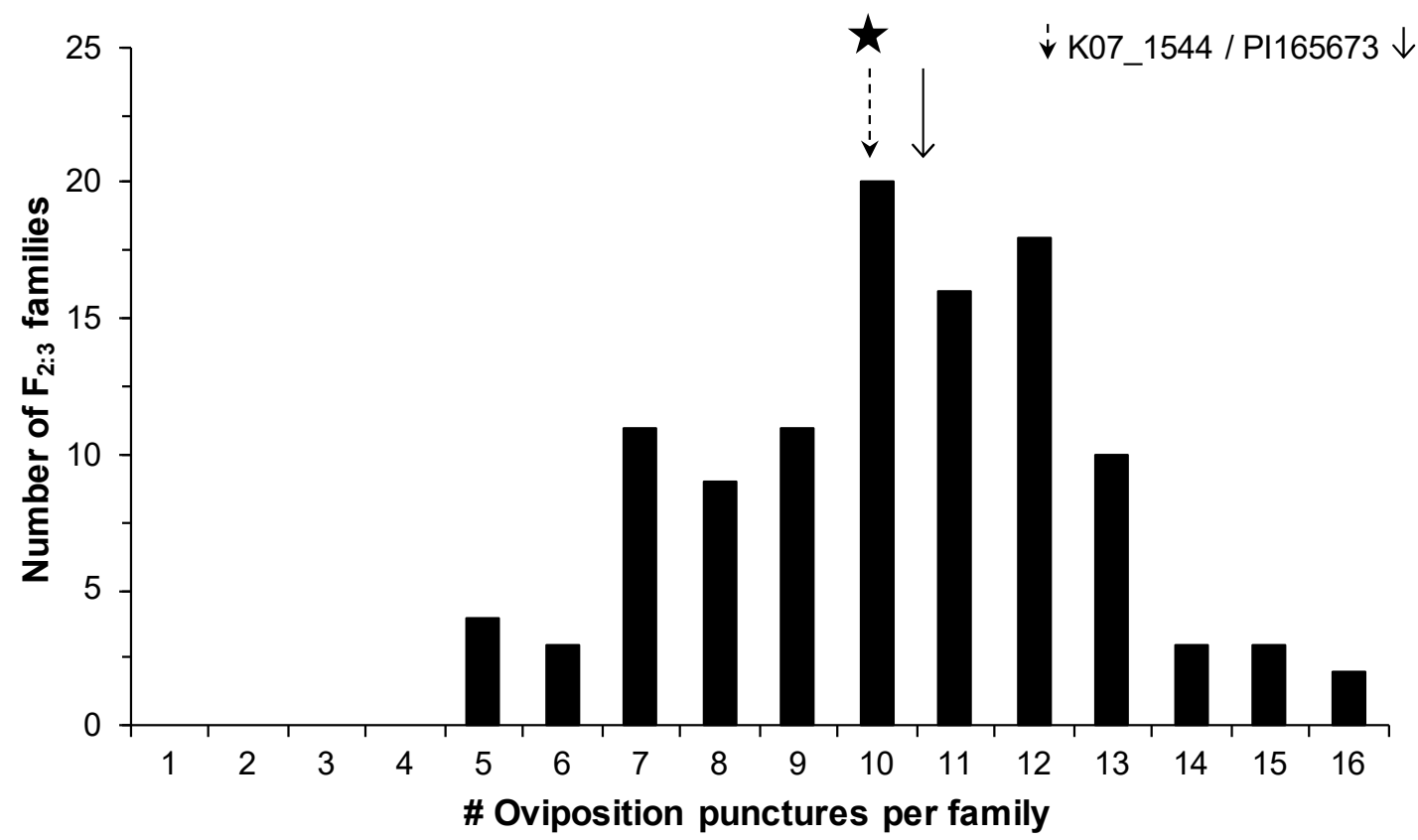

Figure 6. Frequency distribution of number of oviposition punctures per plant in plants from $108 \mathrm{~F}_{2: 3}$ families from the cross K07-1544/PI165673 at $21 \mathrm{~d}$ post infestation with Dectes texanus in 2012. Arrows and star indicate parent and $\mathrm{F}_{2: 3}$ population mean, respectively. 


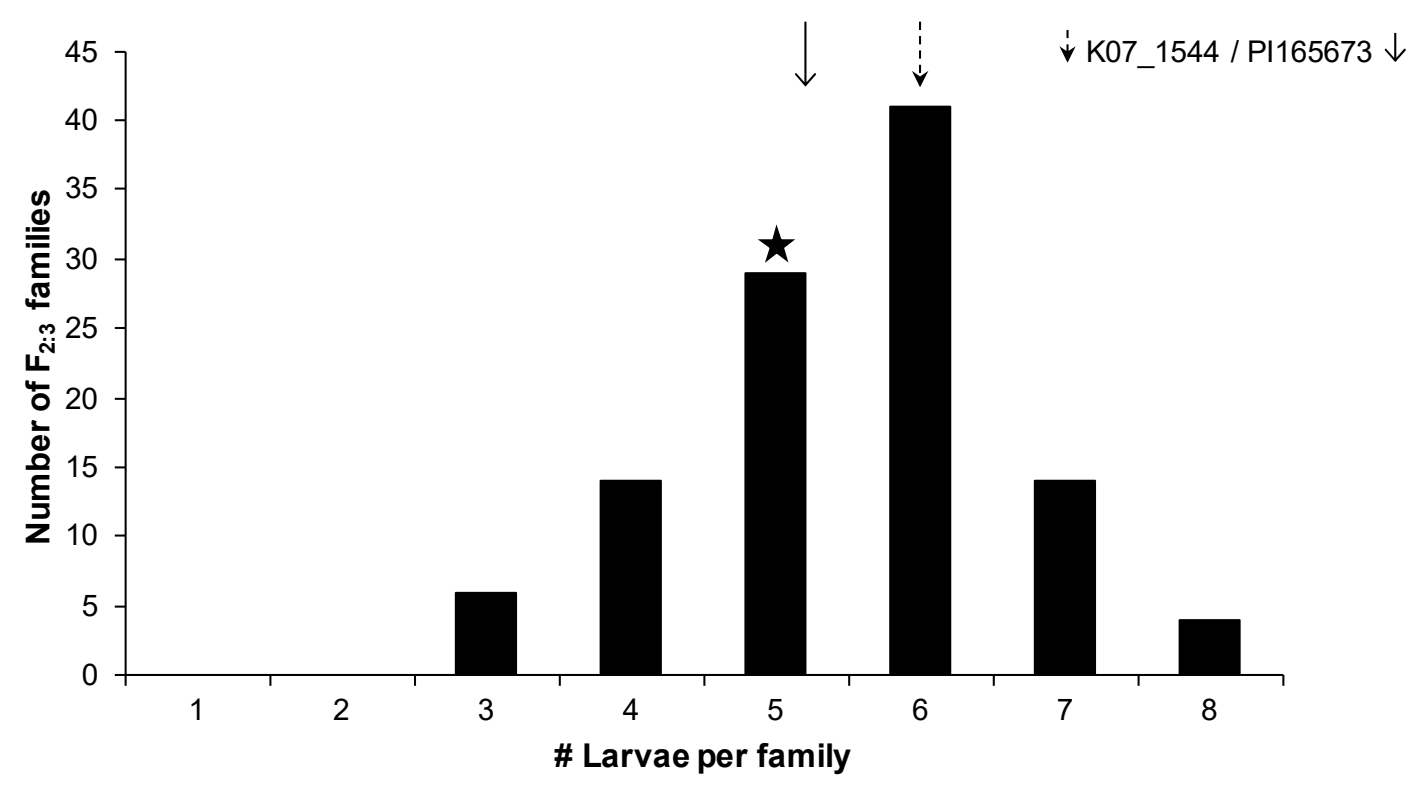

Figure 7. Frequency distribution of number of larvae per plant in plants from $108 \mathrm{~F}_{2: 3}$ families from the cross K07$1544 /$ PI165673 at $21 \mathrm{~d}$ post infestation with Dectes texanus in 2012. Arrows and star indicate parent and $\mathrm{F}_{2: 3}$ population mean, respectively.

Table 3. Chi-square tests for goodness of fit of $\mathrm{F}_{2: 3}$ families K07-1544/PI165673 OL antibiosis ratio.

\begin{tabular}{|c|c|c|c|c|c|c|c|}
\hline & Phenotypic Ratios & & $\begin{array}{l}\text { Observed } \\
\text { Frequencies }\end{array}$ & $\begin{array}{c}\text { Expected } \\
\text { Frequencies }\end{array}$ & $x^{2}$ & df & \\
\hline \multirow[t]{2}{*}{ Single gene } & Dominance & $3: 1$ & $95: 13^{a}$ & $81: 27$ & 9.7 & 1 & $* *$ \\
\hline & Dominance & $1: 2: 1$ & $13: 89: 6^{b}$ & $27: 54: 27$ & 46.3 & 2 & $* *$ \\
\hline \multirow[t]{7}{*}{ Two genes } & Dominance without epistasis & $9: 3: 3: 1$ & $50: 26: 19: 13^{c}$ & $61: 20: 20: 7$ & 9.2 & 3 & * \\
\hline & Additive genes & $9: 6: 1$ & $13: 89: 6^{b}$ & $61: 40: 7$ & 95.7 & 2 & ** \\
\hline & Dominant epistasis & 12:3:1 & $13: 89: 6^{b}$ & $81: 20: 7$ & 289.7 & 2 & $* *$ \\
\hline & Recessive epistasis & $9: 3: 4$ & $13: 89: 6^{b}$ & $61: 20: 27$ & 286.3 & 2 & $* *$ \\
\hline & Duplicate recessive epistasis & $9: 7$ & $95: 13^{a}$ & $61: 47$ & 44.0 & 1 & $* *$ \\
\hline & Duplicate dominant epistasis & $15: 1$ & $95: 13^{a}$ & $101: 7$ & 6.0 & 1 & * \\
\hline & Dominant and recessive epistasis & $13: 3$ & $95: 13^{a}$ & $88: 20$ & 3.2 & 1 & ns \\
\hline
\end{tabular}

OL antibiosis ratio $=($ number of oviposition punctures $/$ number of larvae $) ; \chi^{2}=(\text { observed frequency }- \text { expected frequency })^{2} /$ expected frequency; ${ }^{* *}=$ significant at $1 \%$ level of probability; ${ }^{*}=$ significant at $5 \%$ level of probability; ns $=$ not significant at $1 \%$ and $5 \%$ level. ${ }^{a}$ number of families with OL antibiosis ratio not significantly different from K07-1544: number of families with antibiosis ratio OL significantly higher than K07-1544. ${ }^{\mathrm{b}}$ number of families with OL antibiosis ratio significantly higher than K07-1544: number of families with antibiosis ratio OL not significantly different from K07-1544 and PI165673: number of families with OL antibiosis ratio significantly lower than PI165673. ${ }^{\mathrm{c}}$ number of families with OL antibiosis ratio lower than $1.9=(1.7+\mathrm{d})$ : number of families with antibiosis ratio OL between 1.9 and 2.0: number of families with OL antibiosis ratio between 2.1 and 2.3: number of families with OL antibiosis ratio significantly higher than K07-1544. $\mathrm{d}=(\mathrm{PI} 165673 \mathrm{OL}$ antibiosis ratio OL $-\mathrm{K} 07-1544 \mathrm{OL}$ antibiosis ratio $) / 2=(2.1-1.7) / 2=0.2$.

Table 4. Broad sense heritability percentages using the $\sigma^{2}$ cage and $\sigma^{2}$ cage ${ }^{*}$ genotype variance components from $\mathrm{F}_{2: 3} \mathrm{~K} 07-$ 1544/PI165673 families and parental genotypes infested with Dectes texanus in 2012.

\begin{tabular}{ccccccc}
\hline \multicolumn{5}{c}{ Parental Genotypes } \\
\hline Phenotypic Trait & $\boldsymbol{\sigma}^{2} \boldsymbol{F}_{2: 3}$ Plants & $\boldsymbol{\sigma}^{2}$ cage & $\boldsymbol{\sigma}^{2}$ cage ${ }^{*}$ genotype & $\boldsymbol{\sigma}^{2}$ error & $\boldsymbol{H}^{\mathbf{2}}(\boldsymbol{\%})$ \\
\hline OL antibiosis ratio OL & 1.04 & 0.07 & 0.0001 & 0.59 & 68.5 \\
\hline
\end{tabular}

OL antibiosis ratio = (number of oviposition punctures/number of larvae), parental genotypes: Non-segregant genotypes (susceptible and resistant parents). $H^{2}$ : Broad sense heritability, $H^{2}=\left(\left(\sigma_{\mathrm{F} 2: 3}^{2}-\sigma^{2} \mathrm{e}\right) / \sigma^{2} \mathrm{~F} 2: 3\right) \times 100$, where $\sigma_{\mathrm{F} 2: 3}^{2}$ is the phenotypic variance of the $\mathrm{F}_{2: 3}$ families, and $\sigma^{2}{ }_{\mathrm{e}}=\left(\sigma^{2}\right.$ cage $+\sigma^{2}$ cage ${ }^{*}$ genotype $\left.+\sigma^{2}{ }_{\text {error }}\right) / 2$ is the variance of environmental origin. 


\subsection{Field Experiment with K07-1544 and PI165673 Genotypes}

At $7 \mathrm{~d}$ post infestation, the OL antibiosis ratio was two times higher in the PI165673 compared to $\mathrm{K} 07-1544\left(\mathrm{~F}_{1,8}=6.51, p=0.03\right.$, Table 5). The high OL antibiosis ratio observed in this genotype may be overestimated because only $30 \%$ of the K07-1544 plants contained larvae, whereas $70 \%$ of the PI165673 plants had larvae. The OEL antibiosis ratio; numbers of oviposition punctures, numbers of larvae, numbers of eggs; larval head capsule width, and percentage of larvae per instar were not significantly different between genotypes (Tables 5 and 6).

Table 5. Mean (lower, upper CI) OEL and OL antibiosis ratios; numbers of oviposition punctures, numbers of larvae, numbers of eggs, and larval head capsule width per plant in soybean genotypes K07-1544 and PI165673 infested with Dectes texanus in 2014.

\begin{tabular}{|c|c|c|c|c|c|c|c|}
\hline \multirow[b]{2}{*}{$\begin{array}{l}\text { Sampling } \\
\text { Date (d) }\end{array}$} & \multirow[b]{2}{*}{ Genotype } & \multicolumn{6}{|c|}{ Mean (Lower, Upper CI) } \\
\hline & & $\begin{array}{c}\text { OLE } \\
\text { Antibiosis } \\
\text { Ratio }\end{array}$ & $\begin{array}{c}\text { OL Antibiosis } \\
\text { Ratio }\end{array}$ & $\begin{array}{l}\text { \# Oviposition } \\
\text { Punctures }\end{array}$ & \# Eggs & \# Larvae & $\begin{array}{c}\text { Larval Head } \\
\text { Capsule Width } \\
(\mathrm{mm})\end{array}$ \\
\hline $7^{a}$ & $\begin{array}{l}\text { K07-1544 } \\
\text { PI165673 }\end{array}$ & $\begin{array}{l}1.9(1.2,3.1) \mathrm{A} \\
2.3(1.6,3.8) \mathrm{A}\end{array}$ & $\begin{array}{l}2.3(0.4,4.1) \mathrm{A} \\
4.7(3.5,5.9) \mathrm{B}\end{array}$ & $\begin{array}{c}12.0(2.6,21.4) \mathrm{A} \\
22.2(12.8,31.6) \mathrm{A}\end{array}$ & $\begin{array}{l}5.1(1.7,8.5) \mathrm{A} \\
5.6(2.2,9.0) \mathrm{A}\end{array}$ & $\begin{array}{c}2.1(0.6,7.4) \mathrm{A} \\
4.7(1.4,15.2) \mathrm{A}\end{array}$ & $\begin{array}{c}0.43(0.39,0.47) \mathrm{A} \\
0.5(0.47,0.52) \mathrm{A}\end{array}$ \\
\hline $9^{b}$ & $\begin{array}{l}\text { K07-1544 } \\
\text { PI165673 }\end{array}$ & $\begin{array}{l}1.9(1.5,2.3) \mathrm{A} \\
1.6(1.2,2.1) \mathrm{A}\end{array}$ & $\begin{array}{c}5.7(3.0,10.8) \mathrm{A} \\
10.0(4.3,23.5) \mathrm{A}\end{array}$ & $\begin{array}{c}25.2(15.4,41.4) \mathrm{A} \\
15.0(8.0,28.0) \mathrm{A}\end{array}$ & $\begin{array}{c}6.9(2.1,11.6) \mathrm{A} \\
8.2(2.3,14) \mathrm{A}\end{array}$ & $\begin{array}{c}6.0(2.9,12.4) \mathrm{A} \\
2.0(0.7,5.6) \mathrm{A}\end{array}$ & $\begin{array}{l}0.48(0.42,0.53) \mathrm{A} \\
0.48(0.40,0.55) \mathrm{A}\end{array}$ \\
\hline $11^{\mathrm{c}}$ & $\begin{array}{l}\text { K07-1544 } \\
\text { PI165673 }\end{array}$ & $\begin{array}{l}1.5(0.8,2.9) \mathrm{A} \\
2.1(1.3,3.5) \mathrm{A}\end{array}$ & $\begin{array}{l}5.7(2.8,11.6) \mathrm{A} \\
5.4(2.5,11.7) \mathrm{A}\end{array}$ & $\begin{array}{l}16.1(5.7,26.6) \mathrm{A} \\
15.4(6.2,24.6) \mathrm{A}\end{array}$ & $\begin{array}{l}5.4(1.2,9.6) \mathrm{A} \\
5.9(2.2,9.6) \mathrm{A}\end{array}$ & $\begin{array}{l}5.3(2.7,7.8) \mathrm{A} \\
2.4(0.3,4.6) \mathrm{A}\end{array}$ & $\begin{array}{c}0.5(0.4,0.6) \mathrm{A} \\
0.5(0.47,0.6) \mathrm{A}\end{array}$ \\
\hline $13^{d}$ & $\begin{array}{l}\text { K07-1544 } \\
\text { PI165673 }\end{array}$ & $\begin{array}{l}1.4(0.7,2.8) \mathrm{A} \\
3.7(2.4,5.6) \mathrm{B}\end{array}$ & $\begin{array}{l}3.4(0.1,6.8) \mathrm{A} \\
6.1(3.7,8.5) \mathrm{A}\end{array}$ & $\begin{array}{l}23.6(8.9,38.3) \mathrm{A} \\
28.3(15.2,41.4) \mathrm{A}\end{array}$ & $\begin{array}{c}8.4(4.6,12.2) \mathrm{A} \\
4.5(1.1,7.9) \mathrm{A}\end{array}$ & $\begin{array}{c}6.4(2.3,10.4) \mathrm{A} \\
6.1(2.5,9.7) \mathrm{A}\end{array}$ & $\begin{array}{l}0.48(0.4,0.55) \mathrm{A} \\
0.49(0.4,0.55) \mathrm{A}\end{array}$ \\
\hline $15^{\mathrm{e}}$ & $\begin{array}{l}\text { K07-1544 } \\
\text { PI165673 }\end{array}$ & $\begin{array}{l}1.5(1.2,2.0) \mathrm{A} \\
2.4(1.8,3.1) \mathrm{B}\end{array}$ & $\begin{array}{c}6.3(0.4,12.1) \mathrm{A} \\
12.2(6.9,17.5) \mathrm{A}\end{array}$ & $\begin{array}{c}10.5(1.2,22.2) \mathrm{A} \\
24.5(14.0,34.9) \mathrm{A}\end{array}$ & $\begin{array}{l}3.1(1.3,7.2) \mathrm{A} \\
6.4(3.2,12.9) \mathrm{A}\end{array}$ & $\begin{array}{c}3.1(1.2,7.9) \mathrm{A} \\
5.8(2.6,12.7) \mathrm{A}\end{array}$ & $\begin{array}{l}0.5(0.4,0.7) \mathrm{A} \\
0.6(0.4,0.7) \mathrm{A}\end{array}$ \\
\hline $21^{\mathrm{f}}$ & $\begin{array}{l}\text { K07-1544 } \\
\text { PI165673 }\end{array}$ & $\begin{array}{l}1.8(1.1,2.5) \mathrm{A} \\
2.3(1.8,2.9) \mathrm{A}\end{array}$ & $\begin{array}{l}2.3(1.1,4.9) \mathrm{A} \\
6.4(3.6,11.3) \mathrm{B}\end{array}$ & $\begin{array}{c}18.3(7.3,29.3) \mathrm{A} \\
19.1(10.1,28.1) \mathrm{A}\end{array}$ & $\begin{array}{l}2.0(1.0,5.0) \mathrm{A} \\
4.0(1.6,6.4) \mathrm{A}\end{array}$ & $\begin{array}{c}7.8(2.7,12.9) \mathrm{A} \\
4.7(0.5,8.9) \mathrm{A}\end{array}$ & $\begin{array}{c}0.57(0.52,0.62) \mathrm{B} \\
0.46(0.4,0.51) \mathrm{A}\end{array}$ \\
\hline
\end{tabular}

Means within a column with different uppercase letters per sampling date are significantly different based on an F-test ( $p<0.05)$; d: days post infestation; $\mathrm{CI}=$ confidence interval; $\mathrm{OL}$ antibiosis ratio = (number of oviposition punctures/number of larvae); OEL antibiosis ratio $=$ (number of oviposition punctures/[number of eggs + number of larvae]). Means within a column with same uppercase letter per sampling date are not significantly different based on an F-test $(p>0.05)$ : ${ }^{a}$ number of egg $\left(\mathrm{F}_{1,18}=0.05, p>0.05\right), \mathrm{OEL}$ antibiosis ratio $\left(\mathrm{F}_{1,18}=0.64, p>0.05\right)$; larval head capsule width $\left(\mathrm{F}_{1,8}=0.02, p>0.05\right)$, number of oviposition punctures $\left(\mathrm{F}_{1,18}=2.61, p>0.05\right)$, number of larvae $\left(\mathrm{F}_{1,18}=0.94, p>0.05\right) .{ }^{\mathrm{b}}$ number of oviposition punctures $\left(\mathrm{F}_{1,13}=1.98, p>0.05\right)$, number of eggs $\left(\mathrm{F}_{1,13}=0.13, p>0.05\right)$, and number of larvae $\left(\mathrm{F}_{1,13}=3.59, p>0.05\right)$; the $\mathrm{OEL}$ and $\mathrm{OL}$ antibiosis ratios $\left(\mathrm{F}_{1,13}=0.95, p>0.05 ; \mathrm{F}_{1,10}=1.38, p>0.05\right.$, respectively); larval head capsule width $\left(\mathrm{F}_{1,10}=0.01, p>0.05\right)$. ${ }^{\mathrm{c}}$ number of oviposition punctures $\left(\mathrm{F}_{1,14}=0.01, p>0.05\right)$, number of eggs $\left(\mathrm{F}_{1,14}=0.03, p>0.05\right)$, and number of larvae $\left(\mathrm{F}_{1,14}=3.38, p>0.05\right)$; the OEL and OL antibiosis ratios $\left(\mathrm{F}_{1,14}=0.86, p>0.05 ; \mathrm{F}_{1,11}=0.01, p>0.05\right.$, respectively); larval head capsule width $\left(\mathrm{F}_{1,11}=0.74, p>0.05\right) .{ }^{\mathrm{d}}$ number of oviposition punctures $\left(\mathrm{F}_{1,16}=0.25, p>0.05\right)$, number of eggs $\left(\mathrm{F}_{1,16}=2.61, p>0.05\right)$, and number of larvae $\left(\mathrm{F}_{1,16}=0.01, p>0.05\right)$; OL antibiosis ratio $\left(\mathrm{F}_{1,13}=2.02, p>0.05\right)$; larval head capsule width $\left(\mathrm{F}_{1,13}=0.21, p>0.05\right)$. e number of oviposition punctures $\left(\mathrm{F}_{1,16}=3.56, p>0.05\right)$, number of eggs $\left(\mathrm{F}_{1,16}=1.93, p>0.05\right)$, and number of larvae $\left(\mathrm{F}_{1,16}=1.16\right.$, $p>0.05)$; OL antibiosis ratio $\left(\mathrm{F}_{1,16}=2.56, p>0.05\right)$; larval head capsule width $\left(\mathrm{F}_{1,12}=0.12, p>0.05\right)$. ${ }^{\mathrm{f}}$ number of oviposition punctures $\left(\mathrm{F}_{1,13}=0.01, p>0.05\right)$, number of eggs $\left(\mathrm{F}_{1,13}=1.25, p>0.05\right)$ and number of larvae $\left(\mathrm{F}_{1,13}=1.07, p>0.05\right) ; \mathrm{OEL}$ antibiosis ratio $\left(\mathrm{F}_{1,13}=1.79\right.$, $p>0.05)$.

At 9 and $11 \mathrm{~d}$ post infestation, the numbers of oviposition punctures, eggs, and larvae; OEL and OL antibiosis ratios; larval head capsule widths and percentage of larvae per instar were not significantly different between genotypes (Tables 5 and 6).

At 13 and $15 \mathrm{~d}$ post infestation, the OEL antibiosis ratio was two and 0.6 times significantly higher in PI165673 compared to K07-1544, respectively $\left(\mathrm{F}_{1,16}=6.11, p=0.02\right.$; $\mathrm{F}_{1,16}=6.34, p=0.02$, respectively, Table 5). The OL antibiosis ratios; numbers oviposition punctures, larvae and eggs; and larval head capsule widths were not significantly different between genotypes on both sampling dates (Tables 5 and 6). The percentage of larvae per instar was significantly different between genotypes (Pearson's $\chi^{2}=11.3, \mathrm{df}=1, p=0.03$ ) at $15 \mathrm{~d}$ post infestation where the PI165673 had higher and lower percentage of larvae in first and second instar compared to the K07-1544 (Table 6). 
Table 6. Percentage of larvae per instar in soybean genotypes K07-1544 and PI165673 infested with Dectes texanus in 2014.

\begin{tabular}{|c|c|c|c|c|c|c|c|}
\hline \multirow[b]{2}{*}{ Sampling Date (d) } & \multirow[b]{2}{*}{ Genotype } & \multicolumn{6}{|c|}{$\%$ Larvae per Instar } \\
\hline & & I & II & III & IV & $\mathbf{V}$ & VI \\
\hline \multirow[t]{2}{*}{$7^{a}$} & K07-1544 & $100 \mathrm{~A}$ & $0 \mathrm{~A}$ & - & - & - & - \\
\hline & PI165673 & $93.3 \mathrm{~A}$ & $6.7 \mathrm{~A}$ & - & - & - & - \\
\hline \multirow[t]{2}{*}{$9^{b}$} & K07-1544 & $92.3 \mathrm{~A}$ & $7.7 \mathrm{~A}$ & - & - & - & - \\
\hline & PI165673 & $100 \mathrm{~A}$ & $0 \mathrm{~A}$ & - & - & - & - \\
\hline \multirow[t]{2}{*}{$11^{\mathrm{c}}$} & K07-1544 & $94.1 \mathrm{~A}$ & $5.9 \mathrm{~A}$ & - & - & - & - \\
\hline & PI165673 & $86.4 \mathrm{~A}$ & $13.6 \mathrm{~A}$ & - & - & - & - \\
\hline \multirow[t]{2}{*}{$13^{d}$} & K07-1544 & $97.9 \mathrm{~A}$ & $2.1 \mathrm{~A}$ & - & - & - & - \\
\hline & PI165673 & $88.1 \mathrm{~A}$ & $11.9 \mathrm{~A}$ & - & - & - & - \\
\hline \multirow[t]{2}{*}{$15^{\mathrm{e}}$} & K07-1544 & $58.3 \mathrm{~A}$ & $41.7 \mathrm{~B}$ & $0 \mathrm{~A}$ & - & - & - \\
\hline & PI165673 & $86.4 \mathrm{~B}$ & $10.2 \mathrm{~A}$ & $3.4 \mathrm{~A}$ & - & - & - \\
\hline \multirow[t]{2}{*}{$21^{\mathrm{f}}$} & K07-1544 & $67.4 \mathrm{~A}$ & $26.1 \mathrm{~A}$ & $6.5 \mathrm{~A}$ & - & - & - \\
\hline & PI165673 & $84.4 \mathrm{~A}$ & $14.6 \mathrm{~A}$ & $0 \mathrm{~A}$ & - & - & - \\
\hline \multirow[t]{2}{*}{$120^{g}$} & K07-1544 & - & - & - & $0 \mathrm{~A}$ & $2.9 \mathrm{~A}$ & $97.1 \mathrm{~A}$ \\
\hline & PI165673 & - & - & - & $1.8 \mathrm{~A}$ & $1.8 \mathrm{~A}$ & $96.4 \mathrm{~A}$ \\
\hline
\end{tabular}

d: days post infestation; Larvae in instar stage were not found. ${ }^{e}$ Percentages within a column with different uppercase letter per sampling date are significantly different based on a Fischer's chi-square test $(p<0.05)$. Percentages within a column with same uppercase letter per sampling date are not significantly different based on a Pearson's chi-square test $(p>0.05)$ : ${ }^{\text {a }}$ Pearson's $\chi^{2}=1.5, \mathrm{df}=1, p>0.05 .{ }^{\mathrm{b}}$ Pearson's $\chi^{2}=0.98, \mathrm{df}=1, p>0.05 .{ }^{\mathrm{c}}$ Pearson's $\chi^{2}=0.98, \mathrm{df}=1, p>0.05 .{ }^{\mathrm{d}}$ Pearson's $\chi^{2}=0.07, \mathrm{df}=1, p=0.07 .{ }^{\mathrm{f}}$ Pearson's $\chi^{2}=4.97, \mathrm{df}=2, p=0.06$. g Pearson's $\chi^{2}=0.74, \mathrm{df}=2, p>0.05$.

At $21 \mathrm{~d}$ post infestation, the OL antibiosis ratios and larval head capsule widths were significantly different between genotypes $\left(\left(\mathrm{F}_{1,10}=5.67, p=0.0385 ; \mathrm{F}_{1,9}=13.07, p=0.0056\right.\right.$, respectively). The OL antibiosis ratio was three times significantly higher in the PI165673 compared to K07-1544 (Table 6). Although, larvae-fed PI165673 had significantly smaller average head capsule widths than larvae-fed K07-1544 (Table 5), the percentage of larvae per instar was not significantly different between genotypes (Table 6). The number of oviposition punctures, eggs and larvae, and the OEL antibiosis ratios were not significantly different between genotypes (Table 5).

At $120 \mathrm{~d}$ post infestation, the percentage of stem tunneling, tunnel reaching the plant base, and girdled plants were statistically different between genotypes $\left(\mathrm{F}_{1,9}=20.39\right.$, $p=0.0015$; Pearson's $\chi^{2}=25.9, \mathrm{df}=1, p<0.0001$; Pearson's $\chi^{2}=8.8, \mathrm{df}=1, p=0.0043$, respectively). The percentage of stem tunneling was significantly lower in the PI16573 compared to K07-1544 (Table 7), and none of the PI165673 plants had tunnels reaching the base of the plant or were girdled compared to K07-1544 (69.2 and 30.8\%, respectively). The OL antibiosis ratio; numbers of oviposition punctures, larvae and stem entrance holes; larval head capsule width, and percentage of larvae per instar were not significantly different between genotypes (Tables 6 and 7).

Table 7. Mean (lower, upper CI) OL antibiosis ratios; numbers of oviposition punctures, larvae and stem entrance holes; larval head capsule widths, and percent stem tunneling per plant in soybean genotypes K07-1544 and PI165673 infested with Dectes texanus in 2014.

\begin{tabular}{|c|c|c|c|c|c|c|c|}
\hline \multirow[b]{2}{*}{$\begin{array}{l}\text { Sampling } \\
\text { Date (d) }\end{array}$} & \multirow[b]{2}{*}{ Genotype } & \multicolumn{6}{|c|}{ Mean (Lower, Upper CI) } \\
\hline & & $\%$ Stem Tunneling & $\begin{array}{c}\text { \# Stem Entrance } \\
\text { Holes }\end{array}$ & $\begin{array}{c}\text { Antibiosis Ratio } \\
\text { OL }\end{array}$ & $\begin{array}{l}\text { \# Oviposition } \\
\text { Punctures }\end{array}$ & \# Larvae & $\begin{array}{c}\text { Larval Head } \\
\text { Capsule Width } \\
(\mathrm{mm})\end{array}$ \\
\hline 120 & $\begin{array}{l}\text { K07-1544 } \\
\text { PI165673 }\end{array}$ & $\begin{array}{l}71.7(62.2,81.1) \mathrm{A} \\
50.4(40.4,59.7) \mathrm{B}\end{array}$ & $\begin{array}{l}5.3(3.9,6.7) \mathrm{A} \\
3.6(2.8,4.7) \mathrm{A}\end{array}$ & $\begin{array}{l}13.4(9.9,18.1) \mathrm{A} \\
12.4(9.1,16.7) \mathrm{A}\end{array}$ & $\begin{array}{l}17.7(11.2,28.2) \mathrm{A} \\
27.3(17.1,43.5) \mathrm{A}\end{array}$ & $\begin{array}{l}1.3(0.5,3.3) \mathrm{A} \\
2.4(0.9,5.9) \mathrm{A}\end{array}$ & $\begin{array}{l}2.0(1.9,2.1) \mathrm{A} \\
2.0(1.9,2.1) \mathrm{A}\end{array}$ \\
\hline
\end{tabular}

Means within a column with different uppercase letter per sampling date are significantly different based on an F-test $(p<0.05)$; $\mathrm{d}$ : days post infestation; $\mathrm{CI}=$ confidence interval; Antibiosis ratio $\mathrm{OL}=$ number of oviposition punctures/number of larvae), percentage of stem tunneling $=([$ stem tunnel length/plant length $] \times 100)$. Means within a column with same uppercase letter per sampling date are not significantly different based on an F-test $(p>0.05)$ : Antibiosis ratio OL $\left(\mathrm{F}_{1,7.2}=0.2, p>0.05\right)$, number of oviposition punctures $\left(\mathrm{F}_{1,8.8}=2.05, p>0.05\right)$, number of larvae $\left(\mathrm{F}_{1,9}=2.02 p>0.05\right)$, number of stem entrance holes $\left(\mathrm{F}_{1,8.9}=4.38, p>0.05\right)$, larval head capsule width $\left(\mathrm{F}_{1,9}=1.14, p>0.05\right)$. 


\section{Discussion}

\subsection{Field Experiments with $F_{2}$ and $F_{2: 3}$ Populations}

Information about heritability, and the number and chromosome location of genes involved in plant resistance, facilitates the design of efficient and accurate breeding strategies to develop resistant cultivars [22,41,42]. The lack of differences between both parental genotypes made it difficult to estimate the number of genes conferring resistance and their mode of inheritance in the $\mathrm{F}_{2}$ population using Mendelian and non-Mendelian phenotypic ratios. Extreme phenotypic differences between parental genotypes are desirable to locate genes in the genome and quantify their contribution to the phenotype [41]. Increasing the sample size of K07-15447 and PI165673 contributed to detecting a significant difference in the OL antibiosis ratio between both parental genotypes in 2012 and a resistance controlled by at least two genes with dominant and recessive epistasis using the $\mathrm{F}_{2: 3}$ population. Additionally, the continuous bell-shaped frequency distribution of the number of oviposition punctures, larvae and OL antibiosis ratios in the $\mathrm{F}_{2: 3}$ generation indicated that more than one gene is involved in resistance to D. texanus [31]. Given these results, QTL mapping will be important for the detection and location of genes contributing to $D$. texanus resistance in PI165673 and K07-1544. It remains to be investigated whether K07-1544 also contributes alleles or genes to the resistance found in some of the $\mathrm{F}_{2: 3}$ families. Quantitative resistance to $D$. texanus was expected as most cases of soybean resistance to Coleopterans are explained by more than one gene. Resistance to the Mexican bean beetle, Epilachna varivestis Mulsant, in soybean MBB 80-115, PI229321, PI227687, PI220358, L76-0049, L78-608, and L76-0328 is controlled by more than two genes, although exact numbers were not specified [42-44]. More recently, four single nucleotide polymorphims (SNPs) on chromosome 11 were associated with resistance to E. varivestis in a Genome Wide Association Study in soybean [45] Additionally, nine quantitative trait loci (QTLs) were reported for resistance to the Japanese beetle, Popillia japonica Newman, in an Essex/Forrest population where seven QTLs were mapped on linkage groups A2, N, E, A1, I, F and D2 in the Forrest cultivar [46].

The $68 \%$ heritability for the OL antibiosis ratio among the $\mathrm{F}_{2: 3} \mathrm{~K} 07-1544 / \mathrm{PI} 165673$ population indicates that progress in breeding for resistance to $D$. texanus can be slowly achieved by selecting for high resistance ratios. Therefore, the phenotypic differences observed between the $\mathrm{F}_{2: 3}$ families and the parents may be attributed to contributions from the genetic backgrounds of the parents [31]. However, the environmental variation $\left(\sigma^{2} e\right)$ may have been underestimated, since this was calculated using only the parental variation [47]. The contribution from the $\mathrm{F}_{2: 3}$ family plants to the environmental variation was not included in the $\sigma^{2}$ cage and $\sigma^{2}$ cage ${ }^{*}$ genotype variance components because there was only one plant per $\mathrm{F}_{2: 3}$ family in each cage. Additionally, the plant populations were tested in one location, Kansas. Partitioning of the parental genotype-variance component could be used as an approximation of environmental variance in future studies where plants are evaluated in one location or in one environment.

Broad sense heritability estimates were moderately high for the $\mathrm{F}_{2: 3}$ families, and differences in the OL antibiosis ratio were significant between a few families and the parents. The statistically higher antibiosis ratios in two $\mathrm{F}_{2: 3}$ families (95 and 185) can be explained by a combination of complimentary genes or by transgressive segregation [48]. These families are valuable genetic resources for breeding $D$. texanus because they constitute a new genetic pool for the development of $D$. texanus resistant cultivars [49]. Nevertheless, more data are needed to confirm the resistant phenotype since it is possible that the genes contributing to the resistance are affected by yet uncharacterized environmental factors.

The lack of differences in larval head capsule width, body length and proportion of larvae per instar between PI165673 and K07-1544 plants indicated that: (1) The resistance factors contributing to a reduction in numbers of larvae may not affect larval growth after they initiate feeding in the plant, and (2) one larva may survive in and girdle PI165673 stems. Thus, follow-up experiments were conducted to evaluate the proportion of larvae in younger instar stages and girdling damage in PI165673. 


\subsection{Field Experiment with K07-1544 and PI165673 Genotypes}

PI165673 had higher OEL antibiosis ratios at 13 and $15 \mathrm{~d}$ post infestation which indicates that the sum of eggs and larvae relative to the number of oviposition punctures is lower in the PI165673 compared to K07-1544. Therefore, PI165673 resistance is also associated with changes in the female oviposition behavior because puncture sites often lacked eggs. This behavior was previously described for $D$. texanus on soybean [12] and sunflower [17], but this is the first report on the PI165673 genotype. The high OL antibiosis ratio observed in PI165673 confirmed previous published data where this genotype had a higher ratio than the susceptible control in choice experiments at $21 \mathrm{~d}$ post infestation [26]. Additionally, it confirmed that the PI16573 contains lower D. texanus larval densities relative to oviposition punctures compared to K07-1544. Significant differences between parental genotype and year $(2011,2012,2014)$ interaction were not found at $21 \mathrm{~d}$ post infestation (data not shown). Further experiments are needed to determine if survivorship of larvae is reduced when feeding on PI165673. We recommend assessment of soybean resistance to $D$. texanus using the OEL antibiosis ratio at 13 or $15 \mathrm{~d}$ post infestation to reduce the time in screening soybean resistance to $D$. texanus.

The percentage of second-instar larvae was lower and larval head capsule width was smaller in PI165673 compared to K07-1544 at 15 and 21 d post infestation, respectively, suggesting that first-instar larvae feeding in the PI165673 genotype takes longer to develop. These results are contrary to those observed in 2012 where no differences were detected in the larval head capsule size between genotypes at $21 \mathrm{~d}$ post infestation. Differences in results from both years may be associated with temperature, since 2014 had a mild summer compared to the hot summer in 2012.

Dectes texanus intraspecific cannibalism and competition for resources [12] may explain the lack of differences in the OL antibiosis ratio between genotypes at $120 \mathrm{~d}$ post infestation. Intraspecific cannibalism and competition for the overwintering site reduces the number of larvae per stem to one larva. Additionally, the lack of differences in the head capsule size and percentage of larvae per instar between genotypes at this sampling date suggest that the surviving larvae can compensate or overcome possible PI165673 defenses affecting their development. The plant maturity of each genotype may underestimate the percentage of girdled plants observed at 120 post infestation because K07-1544 plants had reached full development, whereas PI165673 plants were still green, bushy, and in the pod-filling stage. Additionally, the plant height (data not shown) and plant maturity may bias the percentage of tunnels reaching the plant base and stem tunneling, respectively, since K07-1455 plants were shorter and had reached their maximum growth relative to PI165673. Therefore, assessment of PI165673 girdling by D. texanus at the end of the growing season will be best conducted in Southern States where maturity VI soybeans can complete their development.

\section{Conclusions}

In conclusion, PI165673 antibiosis resistance is polygenic and reduces D. texanus egg oviposition, larval density and could affect development of first-instar larvae. However, surviving larvae can tunnel into PI165673 stems, develop until the sixth-instar stage, and potentially cause girdling damage. Therefore, PI165673 resistance needs to be reinforced with other sources of soybean resistance or biotechnological techniques before releasing seed material to farmers. Future screening and evaluation of resistance to D. texanus should include records of larval size, weight, and developmental rate to detect soybean genotypes that impair or slow larval development inside the petioles and stems. Combining a high antibiosis ratio with larval development impairment in a cultivar could provide durable and long-term $D$. texanus resistance.

Supplementary Materials: Supplementary Tables S1 to S4 are available online at https:/ /www.mdpi. com/article/10.3390/agronomy11040738/s1. Table S1: Summary of plant sample size, sampling date and Dectes texanus oviposition. Table S2: Summary of normality and homogeneity of variances verification before F-test per sampling date. Table S3: Summary of data distributions used per 
sampling date to analyze each data variable. Table S4: Mean \pm SEM OL antibiosis ratio, numbers of oviposition punctures, and numbers of larvae per plant in $108 \mathrm{~F}_{2: 3}$ families from the cross between K07-1544 and PI165673 infested with Dectes texanus in 2012.

Author Contributions: Conceptualization, L.M.A.-R., C.M.S., L.L.B. and W.T.S.; methodology, L.M.A.-R. and C.M.S.; conduct experiments, L.M.A.-R.; analysis, L.M.A.-R.; writing-original draft preparation, L.M.A.-R. and C.M.S.; writing-review and editing, L.M.A.-R., C.M.S., L.L.B., B.M., W.T.S., E.D.S., K.Y.Z. and H.N.T. All authors have read and agreed to the published version of the manuscript.

Funding: This research was funded by the Kansas Soybean Commission and Kansas State University Research and Extension.

Institutional Review Board Statement: Not applicable.

Informed Consent Statement: Not applicable.

Data Availability Statement: Not applicable.

Acknowledgments: This is contribution No. 21-214-J from the Kansas Agricultural Experiment Station. We thank Melody Larson, Lisa Tan, Marisol Aguirre-Rojas, Luaay K. Khalaf, John Girvin and WenPo Chuang for technical support. The use of trade names is for the purposes of providing scientific information only and does not constitute endorsement by the United States Department of Agriculture. The USDA is an equal opportunity employer.

Conflicts of Interest: The authors declare no conflict of interest, and the funding agencies had no role in the design of the study; in the collection, analyses, or interpretation of data; in the writing of the manuscript, or in the decision to publish the results.

\section{References}

1. Wang, T. Soybean oil. In Vegetable Oils in Food Technology: Composition, Properties and Uses; Gunstone, F.D., Ed.; Blackwell Publishing: Oxford, UK, 2002; pp. 18-58.

2. Nielsen, N.C. Soybean seed composition. In Soybean: Genetics, Molecular Biology and Biotechnology; Verma, D.P.S., Shoemaker, R.C., Eds.; CAB International: Wallingford, UK, 1996; pp. 127-163.

3. Wilson, R.A. Soybean: Market driven research needs. In Genetics and Genomics of Soybean; Stacey, G., Ed.; Springer: New York, NY, USA, 2008; pp. 3-15.

4. American Soybean Association. SoyStats: A Reference Guide to Important Soybean Facts and Figures; American Soybean Association: St. Louis, MO, USA, 2020; pp. 1-36.

5. Orf, J. Introduction. In Genetics, Genomics and Breeding of Soybeans; Bilyeu, K., Ratnaparkhe, M.B., Kole, C., Eds.; CRC Press, Inc.: Enfield, New Hampshire, 2010; pp. 1-18.

6. Food and Agriculture Organization of the United Nations. FAOSTAT Database. 2019. Available online: http://www.fao.org/ faostat/en/\#data/QC (accessed on 3 February 2021).

7. Panthee, D.R. Varietal improvement in soybean. In The Soybean: Botany, Production and Uses; Singh, G., Ed.; CAB international: Wallingford, UK, 2010; pp. 92-112.

8. Savary, S.; Willocquet, L.; Pethybridge, S.J.; Esker, P.; McRoberts, N.; Nelson, A. The global burden of pathogens and pests on major food crops. Nat. Ecol. Evol. 2019, 3, 430-439. [CrossRef]

9. Daugherty, D.M.; Jackson, R.D. Economic damage to soybeans caused by a cerambycid beetle. Proc. North Cent. Branch Entomol. Soc. Am. 1969, 24, 36.

10. Campbell, W. Sampling coleopterous stem borer in soybean. In Sampling Methods in Entomology; Kogan, M., Herzog, D., Eds.; Springer: New York, NY, USA, 1980; pp. 357-373.

11. Patrick, C.R. Observations on the biology of Dectes texanus texanus (Coleoptera Cerambycidae) in Tennessee. J. Georg. Entomol. Soc. 1973, 8, 277-279.

12. Hatchett, J.H.; Daugherty, D.M.; Robbins, J.C.; Barry, R.M.; Houser, E.C. Biology in Missouri of Dectes texanus, a new pest of soybean. Ann. Entomol. Soc. Am. 1975, 68. [CrossRef]

13. Buschman, L.L.; Sloderbeck, P.E. Pest status and distribution of the stem borer, Dectes texanus, in Kansas. J. Insect Sci. 2010, 10, 1-12. [CrossRef] [PubMed]

14. Tindall, K.V.; Stewart, S.; Musser, F.; Lorenz, G.; Bailey, W.; House, J.; Henry, R.; Hastings, D.; Wallace, M.; Fothergill, K. Distribution of the Long-Horned Beetle, Dectes texanus, in Soybeans of Missouri, Western Tennessee, Mississippi, and Arkansas. J. Insect Sci. 2010, 10, 1-10. [CrossRef] [PubMed]

15. Musser, F.R.; Catchot, A.L., Jr.; Conley, S.P.; Davis, J.A.; DiFonzo, C.; Greene, J.K.; Lorenz, G.M.; Owens, D.; Reisig, D.D.; Roberts, P.; et al. 2019 Soybean Insect Losses in the United States. Midsouth Entomol. 2020, 13, 1-23.

16. Falter, J.M. Dectes sp. (Coleoptera: Cerambycidae): A unique and potentially important pest of soybeans. J. Elisha Mitchell Sci. Soc. 1969, 85, 123. 
17. Rogers, C.E. Cerambycid pests of sunflower: Distribution and behavior in the Southern Plains. Environ. Entomol. 1977, 6, 833-838. [CrossRef]

18. Sloderbeck, P.E.; Buschman, L.L. Aerial insecticide treatments for management of Dectes stem borer, Dectes texanus, in soybean. J. Insect Sci. 2011, 11, 1-10. [CrossRef]

19. Acquaah, G. Front matter. In Principles of Plant Genetics and Breeding; John Wiley \& Sons, Ltd: Hoboken, NJ, USA, 2012; pp. i-xvi.

20. Smith, C.M.; Clement, S.L. Molecular bases of plant resistance to arthropods. Annu. Rev. Entomol. 2011, 57, 309-328. [CrossRef]

21. Buschman, L.L.; Joshi, A.; Sloderbeck, P.; Niide, T. Yield losses associated with Dectes stem borers in soybean and efficacy of fipronil seed treatments, Garden City, 2008. In Field Day 2009. Report of Progress \#1014; Southwest Research Extension Center, Kansas State University: Manhattan, KS, USA, 2009; pp. 84-90.

22. Smith, C.M. Plant Resistance to Arthropods: Molecular and Conventional Approaches; Springer: Dordrecht, The Netherlands, 2005.

23. Richardson, L.G. Resistance of Soybeans to Stem Borer Dectes Texanus Texanus LeConte. Ph.D. Thesis, North Carolina State University, Raleigh, NC, USA, 1975.

24. Kaczmarek, M. A Study of the Soybean Stem Borer Including Life Cycle, Insecticidal Susceptibility and Possible Resistance of Soybean Varieties. MSc. Thesis, Kansas State University, Manhattan, KS, USA, 2003.

25. Whalen, J.; Cissel, B.; Uniatowski, B.; Pesek, J. Evaluate Soybean Varieties for Management of Dectes Stem Borer in Soybeans; United Soybean Board: Newark, DE, USA, 2010.

26. Niide, T.; Higgins, R.A.; Whitworth, R.J.; Schapaugh, W.; Smith, C.M.; Buschman, L. Antiobisis resistance in soybean plant introductions to Dectes texanus (Coleoptera: Cerambycidae). J. Econ. Entomol. 2012, 105, 598-607. [CrossRef]

27. Niide, T. Development of Soybean Host Plant Resistance and Other Management Options for the Stem Borer, Dectes Texanus LeConte. Ph.D. Thesis, Kansas State University, Manhattan, KS, USA, 2009.

28. Littell, R.C.; Milliken, G.A.; Stroup, W.W.; Wolfinger, R.D. SAS System for Mixed Models; SAS Institute, INC.: Cary, NC, USA, 1996.

29. Stroup, W.W.; Milliken, G.A.; Claassen, E.A.; Wolfinger, R.D. SAS for Mixed Models: Introduction and Basic Applications.; SAS Institute Inc.: Cary, NC USA, 2018.

30. Milliken, G.; Johnson, D. Analysis of Messy Data. Volume 1; Chapman \& Hall/CRC Press: New York, NY, USA, 2009.

31. Allard, R.W. Principles of Plant Breeding; John Wiley \& Sons, Inc.: New York, NY, USA, 1960.

32. Kansas Mesonet. Kansas Mesonet historical data: KSU Ashland Bottoms Research Station. 2019. Available online: https: / / mesonet.k-state.edu/ (accessed on 14 March 2019).

33. Smirnov, N.V. Estimate of deviation between empirical distribution functions in two independent samples. Bull. Moscow Univ. $1939,2,3-16$.

34. Levene, H. Robust tests for the equality of variance. In Contributions to Probability and Statistics: Essays in Honor of Harold Hotelling; Olkin, I., Ghurye, S.G., Hoeffding, W., Madow, W.G., Mann, H.B., Eds.; Stanford University Press: Palo Alto, CA, USA, 1960; pp. 278-292.

35. Brown, M.B.; Forsythe, A.B. Robust tests for equality of variances. J. Am. Stat. Assoc. 1974, 69, 364-367. [CrossRef]

36. Stroup, W.W. Generalized Linear Mixed Models: Modern Concepts, Methods and Applications; Chapman \& Hall/CRC Press: New York, NY, USA, 2012.

37. Stroup, W.W. Rethinking the analysis of non-normal data in plant and soil science. Agron. J. 2015, 107, 811-827. [CrossRef]

38. SAS Institute. Chapter 49: The GLIMMIX procedure. In SAS/STAT 15.1 User's Guide; SAS Institute INC.: Cary, NC, USA, 2018; pp. 3612-3947.

39. Kenward, M.G.; Roger, J.H. Small sample inference for fixed effects from restricted maximum likelihood. Biometrics 1997, 53, 983-997. [CrossRef]

40. SAS Institute. Chapter 44: The FREQ procedure. In SAS/STAT 15.1 User's Guide; SAS Institute INC.: Cary, NC, USA, 2018; pp. 64-216.

41. Alonso-Blanco, C.; Koornneef, M.; Ooijen, J.W. QTL Analysis. In Arabidopsis Protocols; Sanchez-Serrano, J., Salinas, J., Eds.; Humana Press Inc.: Totowa, NJ, USA, 2006; Volume 323, pp. 79-99.

42. Mebrahtu, T.; Kenworthy, W.; Elden, T. Genetic study of resistance to the Mexican bean beetle in soybean lines. J. Genet. Breed. 1990, 44, 7-12.

43. Sisson, V.A.; Miller, P.A.; Campbell, W.V.; Van Duyn, J.W. Evidence of inheritance of resistance to the Mexican bean beetle in soybeans. Crop Sci. 1976, 16, 835-837. [CrossRef]

44. Rufener, G.K.; St. Martin, S.K.; Cooper, R.L.; Hammond, R.B. Genetics of antibiosis resistance to Mexican bean beetle in soybean. Crop Sci. 1989, 29, 618-622. [CrossRef]

45. Chang, H.-X.; Hartman, G.L. Characterization of insect resistance loci in the USDA Soybean Germplasm Collection using Genome-Wide Association Studies. Front. Plant Sci. 2017, 8, 670. [CrossRef] [PubMed]

46. Yesudas, C.R.; Sharma, H.; Lightfoot, D.A. Identification of QTL in soybean underlying resistance to herbivory by Japanese beetles (Popillia japonica, Newman). Theor. Appl. Genet. 2010, 121, 353-362. [CrossRef] [PubMed]

47. Sleper, D.A.; Poehlman, J.M. Breeding Field Crops, 5th ed.; Blackwell Publishing: Ames, IA, USA, 2006.

48. Rieseberg, L.H.; Archer, M.A.; Wayne, R.K. Transgressive segregation, adaptation and speciation. Heredity 1999, 83, 363-372. [CrossRef] [PubMed]

49. DeVicente, M.C.; Tanksley, S.D. QTL analysis of transgressive segregation in an interspecific tomato cross. Genetics 1993, 134, 585-596. [CrossRef] [PubMed] 